ORIGINAL PAPER

Eur. J. Histochem

45: $267-278,200$

(C) Luigi Ponzio e figlio - Editori in Pavia

\title{
Glyconjugates in epidermal, branchial and digestive mucous cells and gastric glands of gilthead sea bream, Sparus aurata, Senegal sole, Solea senegalensis and Siberian sturgeon, Acipenser baeri development
}

\author{
C. Sarasquete ${ }^{1}$, E. Gisbert ${ }^{2}$, L. Ribeiro ${ }^{3}$, L. Vieira ${ }^{3}$, and M.T. Dinis ${ }^{3}$
}

${ }^{1}$ Instituto de Ciencias Marinas de Andalucía. CSIC. Polígono Rio San Pedro. Apdo oficial. 11510. Puerto Real. Cádiz (Spain); ${ }^{2}$ Laboratorio de Acuicultura, Dpto. Biología Animal, Facultad de Biología, Universitat de Barcelona, Av. Diagonal, 645. 08028. Barcelona, (Spain) and ${ }^{3}$ Unidade de Ciencias e Tecnologias dos Recursos Aquaticos. Universidade do Algarve. 8000. Faro (Portugal)

Accepted: $12 / 2 / 01$

Key words: histochemistry, carbohydrates, proteins, glycoproteins, mucous cells, gastric glands, sea bream, sole, sturgeon, larvae

\section{SUMMARY}

Epidermal, branchial and digestive mucous cells, and the gastric glands of larvae/postlarvae (from hatching until 45 days posthatching) of three fish species (two teleostean and a chondrostean) were investigated using conventional histochemical methods (periodic acid schiff -PAS-, diastase-PAS; alcian blue $\mathrm{pH} 0.5,1$ and 2.5) in order to distinguish neutral and acidic (carboxylated and sulphated) glycoconjugates, as well as bromophenol blue reaction for identification of proteins. Additionally, the presence and distribution of sugar residues in the oligosaccharide side chains of glycoconjugates were investigated using horseradish peroxidase (HPR)-conjugated lectins (Con A, DBA, WGA and UEA-I). Most mucous cells (digestive, epidermal and branchial) of Siberian sturgeon, Acipenser baeri, sea bream, Sparus aurata and Senegal sole, Solea senegalensis larvae were PAS- and alcian blue- (pH 2.5 and 0.5 ) positive, with small variations between organs/tissues and species. Bromophenol blue reaction (general proteins) was positive in a minority of the mucous cells, usually in those cells which were PAS-negative. Proteins rich in sulphydryl (-SH) and/or disulphide (-S-S-) groups related with the glycoprotein nature of the glycoconjugates present in mucous cells were also observed. Epidermal, branchial and digestive mucous cells of all studied larvae did not contain glycogen or lipids.

Con A lectin staining was negative in all mucous cells types of sea bream and sole, but oesophageal mucous cell of sturgeon were reactive to different lectin reactions, suggesting the presence of mannose -Man- and/or glucose -Glc-, L-fucose -Fuc- ; Nacetyl-D-galactosamine -GalNAc-, as well as Nacetyl-D-glucosamine- GlcNAc - and/or sialic acid -NANA- residues. Digestive mucous cells of all studied larvae were positive to WGA and DBA lectins. Epidermal and branchial mucous cells of sea bream and sole were Con A, DBA and UEA-I unreactive. However, mucous cells of sturgeon larvae were stained with UEA-I lectin.

Gastric glands appear very early in sturgeon stomach larvae development (between 5-6 days posthatching) but rather late (around 40 days) during the ontogeny of sole and sea bream larvae. These glands contain neutral glycoproteins with Man and/or Glc, Fuc, GlcNAc- and/or sialic acid and rich in GalNAc- sugar residues, as well as proteins moderately rich in arginine, and others particularly rich in tyrosine and tryptophan . 


\section{INTRODUCTION}

The histomorphological development of gilthead sea bream, Sparus aurata, Senegal sole, Solea senegalensis and Siberian sturgeon, Acipenser baeri larvae and juveniles was studied previously by Sarasquete et al. (1993, 1995, 1996, 1998); Domeneghini et al. (1998), Ribeiro et al. (1999), Gisbert et al. (1998, 1999) and Vieira (2000). In the present study, we show a histochemical comparative study of mucous cells of skin, gills and digestive tract (oesophagus and intestine), before and during gastric gland development (until 45 days posthatching) in these species (two teleostean fish: Senegal sole and sea bream and a chondrostean species: Siberian sturgeon), these species present very different developmental patterns (yolk-sac exhaustion, metamorphosis, digestive, branchial and epidermal development, etc.), as well as different life styles and feeding habits.

In fish, the mucous or goblet cells produce the mucins -glycoconjugate content- which covers the body, and these cells are distributed over the skin, on the gills and line the digestive tract (Roberts, 1978; Gona, 1979; Groman, 1982). In mammals glycoconjugates exert a large variety of functions: mechanical, antimicrobial, antiviral, osmotic, ionic transport, etc. (Allen, 1981). Gut mucosubstances may also exert an osmotic function in fish (Smith, 1989). Mucins, the main constituents of mucus, are high molecular weight glycoproteins. About $50 \%$ of their dry weight can consist of carbohydrate chains (Strous and Dekker, 1992).

Digestive efficiency in fish depends on the proteolytic action of pancreatic juice, goblet cell secretions and intracellular digestion (Kapoor et al., 1975). Glycoconjugates containing neutral sugars protect the mucosa against proteolytic degradation, and may also have a buffering effect on the high acidity of the stomach contents (Smith, 1989; Scocco et al., 1996). On the other hand, the presence of neutral mucins and alkaline phosphatase activity in the digestive epithelium of fish could be positively correlated with absorption and transport of macromolecules through membranes (Stroband et al., 1979). To prevent physical and chemical damage to the gut lining, acid glycoproteins probably act as a lubricant to the fibre-rich material in the gut. They have also a role in the assimilation of nutrients from plants (Tibbets, 1997).
In fish, active ionoregulation begins in the early stages of larval development. Since gills and kidney are still poorly developed at these stages (until metamorphosis), the skin has been presumed to be the functional site of ionoregulation (Morrison, 1993). Instead of branchial respiration, fish larvae rely on cutaneous gas exchange. Even if larvae possessed morphologically differentiated gills, branchial respiration would be rather ineffective (Segner et al., 1994).

Mucous cells and the composition of the mucins they produce are influenced by endogenous factors (sex, development stage, etc.) and exogenous factors, such as stress acid and infections (Ferguson $e t$ al., 1992). Mucous secretion of skin and gills may be important in natural defense against parasites and pathogenic microorganisms (Fletcher, 1978). On the other hand, changes in the number and dimension of mucous cells of gills and skin can be an indicator of pathological or inflammatory processes induced by adverse environmental conditions (Lemoine and Olivereau, 1971; Wendelaar-Bonga and Lock, 1992; Ortiz et al., 1999). The sialic acid content has been used to estimate the degree of skin mucification in fishes (Arillo et al., 1979). Moreover, sialitation and sulphation of glycoproteins, the main component of the mucous cells, may be important for increasing the resistence of mucous to bacterial degradation (Rhodes et al., 1985).

Comparison of the glycoconjugate composition of mucous secretion in larvae and adult fish reveals remarkable inter- and intra-specific differences (Madrid et al., 1989; Illana, 1993; Pajak and Danguy, 1993; Sarasquete et al., 1995; 1996; 1998; Burkhardt-Holm, 1997; Domeneghini et al., 1998, 1999; Ribeiro et al., 1999; Gisbert et al., 1998, 1999; Arellano et al., 1999). This variety can be attributed not only to different feeding habits, but possibly to different taxonomic position, development and biology (Reifel and Travill, 1977, 1978, 1979; Domeneghini et al., 1998, 1999).

\section{MATERIALS AND METHODS}

Siberian sturgeon, Acipenser baeri, Senegal sole, Solea senegalensis and sea bream, Sparus aurata larvae/postlarvae, from hatching until day 45 posthatching were fixed in Bouin solution or in $10 \% \mathrm{v} / \mathrm{v}$ buffered formaldehyde $(\mathrm{pH}$ 7.2) and 
embedded in paraffin. Histological sections of whole specimens of 5-7 $\mu \mathrm{m}$ thickness were stained with haematoxylin-eosin and haematoxylin-V.O.F (light green-orange $\mathrm{G}$-acid fuchsin) according to Gutierrez (1990). The cytochemical tests for carbohydrates (PAS, diastase-PAS; alcian blue $\mathrm{pH}$ $0.5,1$ and 2.5, acetylation, saponification, chlorhydric hydrolysis, neuraminidase-type $\mathrm{V}$ from Clostridium perfringens, bacterial hyaluronidase from Streptomices hyalurolyticus), as well as for glycoproteins (lectins), general proteins (bromophenol blue), proteins rich in lysine (ninhydrinSchiff); proteins rich in tyrosine (Hg-sulphate-sulfuric acid-sodium nitrate); proteins rich in trytophan (P-dimethylaminobenzaldehyde), proteins rich in arginine (1,2 napthoquinone-4-sulphonic acid salt sodium); -SH and -S-S- (sulphydryl and disulphide groups; ferric ferricyanide-Fe III and thioglycollate reduction) and lipids (Oil Red 0 and Sudan black B in cryostat sections) used in this study are described by Pearse (1985) and Bancroft and Stevens (1990).

For the lectin analysis of glycoconjugates, sections were treated with $0.3 \%$ hydrogen peroxide for 10 minutes (to inhibit endogenous peroxidase) in Tris buffered saline (TBS) at $\mathrm{pH}$ 7.2. The sections were incubated for 30 minutes at room temperature in the presence of the following horseradish peroxidase-conjugated lectins (HPR-lectin conjugated) dissolved in TBS $(20 \mu / \mathrm{ml})$ : ConA (mannose-Manand/or glucose-Glc-), WGA (N-acetyl-D-glucosamine-GlcNAc- and/or sialic acid-NANA-), DBA (N-acetyl-D-galactosamine-GalNAc-) and UEA-I (L-Fucose -Fuc-). After three washes in TBS, peroxidase activity was visualized with TBS containing $0.05 \%$ 3,3'diaminobenzidine tetrahydrochloride and $0.015 \%$ hydrogen peroxide. Sections were washed in running tap water for $10 \mathrm{~min}$ utes, dehydrated, cleared and mounted in Eukitt.

Controls were: omission of the respective lectin; substitution of lectin-HPR conjugates by TBS and treatments with different enzymes (neuraminidase Type V - 0.9 U/mg Prot-; $\beta$-galactosidase Grade VI $-400 \mathrm{U} / \mathrm{mg}$ Prot-; $\alpha$-mannosidase Type III -20 $\mathrm{U} / \mathrm{mg}$ Prot -and $\beta-\mathrm{N}$-acetylglucosaminidase -0.25 U/mg Prot-: L-fucosidase -20U/mg Prot).

Lectins and enzymes were purchased from Sigma Chemical Co., St. Louis, MO, USA.

\section{RESULTS}

The histochemical characteristics of carbohydrates/glycoconjugates, proteins and lipids in gastric glands of stomach, intestinal enterocytes and mucous cell secretions of digestive tract (oesophagus and intestine), gills and skin of the Siberian sturgeon, Acipenser baeri, sea bream, Sparus aurata and Senegal sole, Solea senegalensis during different stages of larvae/postlarvae development are shown in Tables I-III. Some of these histochemical results are shown in Figures 1-4.

The species studied presented some histochemical differences in oesophageal mucous cell glycoconjugate content (Table I). The secretory cells of the distal oesophageal zone, close to the undeveloped stomach or to the functional stomach, secreted large amounts of neutral glycoconjugates, and those cells of the proximal pharynx-oesophageal zone produced, in addition to a minor component of neutral glycoconjugates, a great quantity of acidic glycoconjugates, sulphated and carboxylated with sialic acid substituted at C8.

The gastric mucosa of sea bream, sole and sturgeon secreted a large quantity of neutral glycoconjugates, together with small amounts of sialoglycoconjugates. Sialosulphomucins were not observed in gastric glands, which contained neutral glycoproteins with GalNAc, Fuc, GlcNAc and Man and/or Glc sugar residues. In all studied species, when gastric glands were developed, they were strongly positive to general and specific protein reagents, such as stains for tyrosine, arginine, lysine, tryptophan, and $-\mathrm{SH}$ and $-\mathrm{S}-\mathrm{S}$ - groups (Table II).

During the endogenous feeding period of sea bream, sole and sturgeon larvae, the epithelium that lines the developing gut secreted a moderate quantity of neutral glycoconjugates. Most intestinal mucous cells presented a combination of neutral and acidic glycoproteins, while a few of them contained mainly acidic or neutral glycoproteins (Table I). These acidic mucins were composed by both sialomucins and sulphoglycoconjugates.

While epidermal mucous cells of sturgeon, sole and sea bream larvae (and those of gills in sturgeon) appear very early during larval development (at 3-4 days post hatching), branchial mucous cells are developed around 40 days posthatching in sea bream and sole. Initially, epidermal mucous cells secreted neutral mucins (PAS and diastase-PAS pos- 
Table I

Proteins and glycoconjugates in mucous cells of oesophagus and intestine of Siberian sturgeon, Acipenser baeri, Senegal sole, Solea senegalensis and sea bream, Sparus aurata larvae

\begin{tabular}{|c|c|c|c|c|c|c|}
\hline & \multirow[b]{2}{*}{ Sturgeon } & \multicolumn{2}{|c|}{ Oesophagus } & \multicolumn{3}{|c|}{ Intestine } \\
\hline & & Solea & sea bream & Sturgeon & Solea & sea bream \\
\hline Neutral Glycoproteins $(P-A)$ & $2-3$ & $1-2$ & $2-3$ & 3 & 2 & $0-3$ \\
\hline Glycogen & 0 & 0 & 0 & 0 & 0 & 0 \\
\hline Sialoglycoproteins $(P-A)$ & $1-3$ & $1-2$ & $1-2$ & 3 & 3 & 3 \\
\hline Sulphated-glycoproteins $(P-A)$ & ) $1-3$ & $1-2$ & $1-3$ & 3 & $0-1$ & 3 \\
\hline Man/Glc & 1 & 0 & 0 & 0 & 0 & 0 \\
\hline Fuc & $0-1$ & 0 & 0 & $2-3$ & 0 & 0 \\
\hline GlcNAc/Nana & $0-1$ & 2 & 3 & $2-3$ & $1-3$ & $1-2$ \\
\hline GalNAc & $0-1$ & $0-2$ & $1-3$ & 3 & 1 & 2 \\
\hline Lipids & 0 & 0 & 0 & 0 & 0 & 0 \\
\hline Proteins & 2 & $0-1$ & $0-1$ & 2 & 1 & 1 \\
\hline$-S-S-$ groups & 3 & $0-1$ & $0-1$ & 2 & 1 & $0-1$ \\
\hline
\end{tabular}

Intensity of reactions: 0: negative; 1: weak; 2 : moderate and 3 strong histochemical reactivity. A: anterior oesophageal portion; $\mathrm{P}$ : posterior oesophageal portion.

itivity), but progressively during larval development some mucous cells were strongly stained with Alcian Blue $\mathrm{pH} 0.5$ and 2.5, and especially with alcian blue $\mathrm{pH} 1$ (sulphated groups weakly ionized) When alcian blue $\mathrm{pH}$ 2.5-PAS reaction was performed, most mucous cells stained blue (carboxylated groups); some cells stained red (neutral mucins) and a few mucous cells stained purple, indicating a combination of neutral and acidic mucins. PAS reactivity was weakly increased after saponification, suggesting the presence of acetylated sialic acids Moreover, sialic acid was also evidenced in epidermal mucous cells with WGA-lectin, because a sligh decrease in WGA staining and a decreased alcianophilia (alcian blue $\mathrm{pH}$ 2.5) after neuraminidase treatment were observed in these mucous cells. Epidermal and branchial mucous cells of sea bream and sole larvae were ConA, UEA-I and DBA unreactive. However, Fuc (UEA-I lectin) residues were detected in digestive, epidermal and branchial mucous cells of sturgeon (Table III).

\section{DISCUSSION}

According to the histological/histochemical characteristics, oesophageal mucous cells of Siberian sturgeon, Acipenser baeri larvae seemed to be fully developed and functional between 7-8 days posthatching ( 2 days before the onset of exoge- nous feeding). This fact (Gisbert et al., 1998, 1999) differs from different teleostean fish larvae, such as turbot, Scophthalmus maximus (Cousin and Baudin-Laurencin 1985); Dover sole, Solea solea (Boulhic and Gabaudan, 1992); sea bream, Sparus aurata (Sarasquete et al., 1995; Domeneghini et al., 1998) and Senegal sole, Solea senegalensis (Sarasquete et al., 1996; Ribeiro et al., 1999), whose oesophageal mucous cells appear and differentiate later in development.

All the studied species presented some histochemical differences in oesophageal mucous cell glycoconjugate content considering that the secretory cells of the distal oesophageal zone secrete large amounts of neutral glycoconjugates. However, the secretory cells of the proximal pharynx-oesophageal zone produced, in addition to a minor component of neutral glycoconjugates, a great quantity of acidic glycoconjugates, sulphated and carboxylated with sialic acid substituted at $\mathrm{C} 8$. These results were shown in Senegal sole larvae, and previously observed in sea bream (Domeneghini et al., 1998) and in Siberian sturgeon (Gisbert et al., 1999). The acidic glycoconjugates present in white sturgeon, Acipenser transmontanus oesophagus, were shown to be of the sialylated type, so that the mucosal secretion is likely rather fluid (Domeneghini et al., 1999). A combination of mucosubstances (neutral and acidic) was described as a mechanism that allows the alimentary canal of young fish to respond 

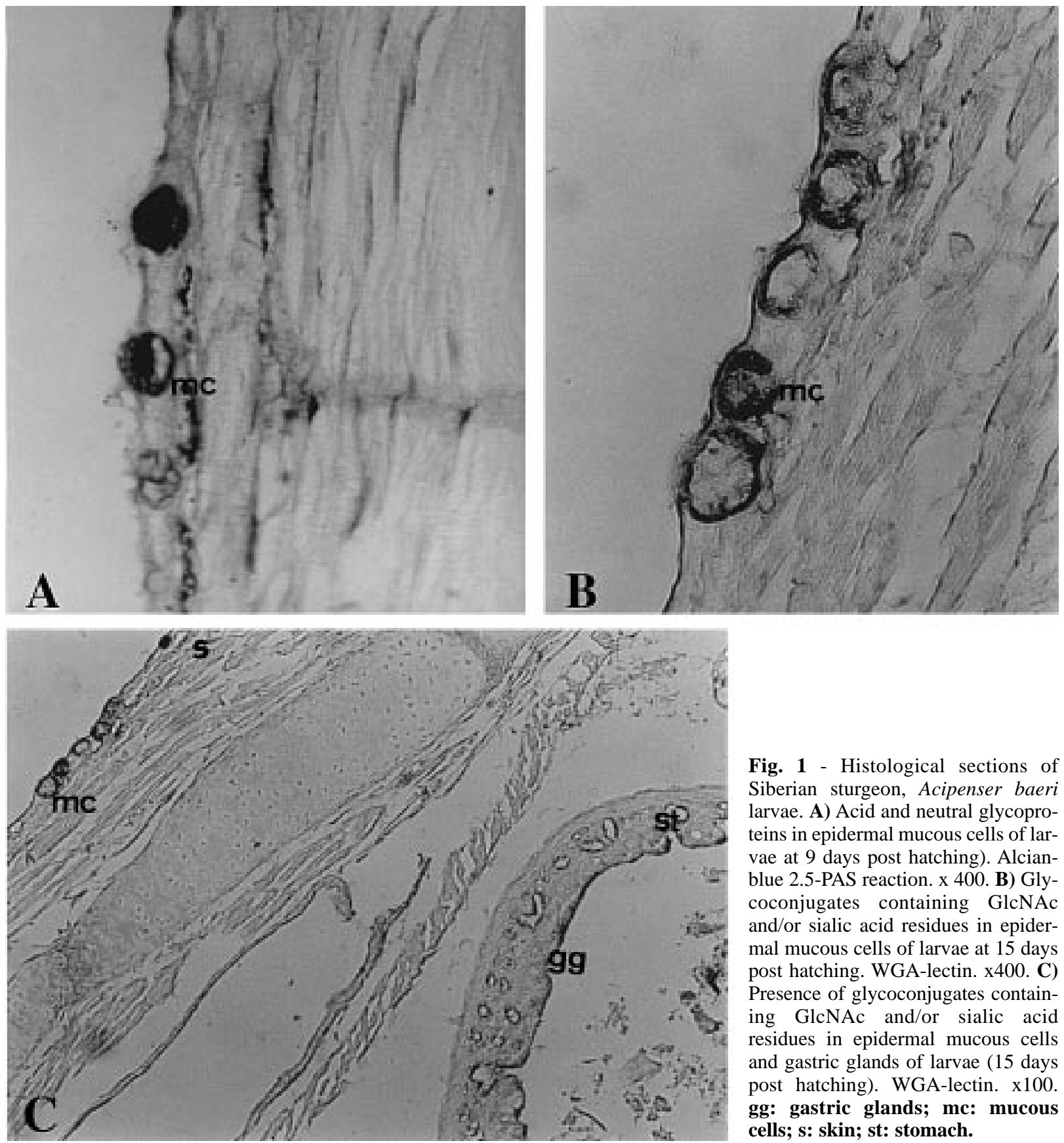

Fig. 1 - Histological sections of Siberian sturgeon, Acipenser baeri larvae. A) Acid and neutral glycoproteins in epidermal mucous cells of larvae at 9 days post hatching). Alcianblue 2.5-PAS reaction. x 400. B) Glycoconjugates containing GlcNAc and/or sialic acid residues in epidermal mucous cells of larvae at 15 days post hatching. WGA-lectin. $x 400$. C) Presence of glycoconjugates containing GlcNAc and/or sialic acid residues in epidermal mucous cells and gastric glands of larvae (15 days post hatching). WGA-lectin. x100. gg: gastric glands; mc: mucous cells; s: skin; st: stomach.

to different changes in environmental conditions early on. The large number of oesophageal mucous cells and the large amount of mucins secreted, however, may not be explicable simply as a lubricant (Reifel and Travill, 1977; Scocco et al., 1998). As was reported by Zimmer et al. (1992), the presence of sialic acid residues prevents viruses from recognising their receptor determinants, and also protects the mucosa from attack by sialidase produced by bacteria. Furthermore, neutral glycoconjugates secreted by mucous cells are reputed to cooperate in the enzymatic digestion of food and in transforming it into chyme, as well as in absorptive functions in other regions of the alimentary canal (Grau et al., 1992; Murray et al., 1994).

On the other hand, it is important to note that buccal 
Table II

Glycoconjugates, proteins and lipids in intestinal enterocytes and in gastric glands of Siberian sturgeon, Acipester baeri, Senegal sole, Solea senegalensis and sea bream, Sparus aurata larvae

\begin{tabular}{|c|c|c|c|c|c|c|}
\hline & \multicolumn{3}{|c|}{ Cytoplasm/Brush Border } & \multicolumn{3}{|c|}{ Gastric Glands } \\
\hline & Sturgeon & Solea & Seabream & Sturgeon & Solea & Seabream \\
\hline Neutral Glycoproteins & $1 / 3$ & $1 / 2$ & $1 / 2$ & 3 & 1 & 1 \\
\hline Glycogen & $2 / 1$ & $2 / 1$ & $1 / 1$ & 0 & 0 & 0 \\
\hline Sialo-glycoproteins. & $1 / 1$ & $0-3$ & $1 / 1$ & 0 & 0 & 0 \\
\hline Sulphated-glycoproteins & $0 / 0$ & $3 / 0$ & $1 / 0$ & 0 & 0 & 0 \\
\hline Man/Glc & $1 / 1$ & $2 / 2$ & $1 / 1$ & 1 & 1 & 1 \\
\hline Fuc & $2 / 2$ & $2 / 2$ & $1 / 1$ & 1 & 1 & 1 \\
\hline GlcNAc/Nana & $0 / 3$ & $1 / 2$ & $2 / 3$ & 2 & 1 & 1 \\
\hline GalNAc & $2 / 3$ & $1 / 1$ & $2 / 2$ & 1 & 1 & 1 \\
\hline Lipids & $2 / 0$ & $2 / 2$ & $2 / 0$ & $0-1$ & $0-1$ & $0-1$ \\
\hline Proteins & $2 / 3$ & $2 / 3$ & $2 / 3$ & $2-3$ & $2-3$ & $2-3$ \\
\hline Arginine & $2 / 2$ & $1 / 2$ & $1 / 2$ & $2-3$ & $2-3$ & $2-3$ \\
\hline Tyrosine & $2 / 2$ & $1 / 2$ & $1 / 2$ & 3 & 3 & 3 \\
\hline Tryptophan & $0 / 0$ & $1 / 2$ & $1 / 2$ & 3 & 3 & 3 \\
\hline Lysine & $1 / 1$ & $2 / 3$ & $1 / 2$ & 1 & 1 & 1 \\
\hline -SH (sulphydryl groups & $1 / 1$ & $1 / 2$ & $1 / 1$ & 1 & 1 & 1 \\
\hline -S-S-(disulphyde groups) & $1 / 2$ & $2 / 3$ & $2 / 2$ & 2 & 2 & $2-3$ \\
\hline
\end{tabular}

Intensity of reactions: 0 : negative; 1 : weak; 2 : moderate and 3 strong histochemical reactivity

Table III

Proteins and glycoconjugates in mucous cells of skin and gills of Siberian sturgeon, Acipester baeri, Senegal sole, Solea senegalensis and sea bream, Sparus aurata larvae

\begin{tabular}{|c|c|c|c|c|c|c|}
\hline & \multicolumn{3}{|c|}{ Skin } & \multicolumn{3}{|c|}{ Gills } \\
\hline & Sturgeon & Solea & Seabream & Sturgeon & Solea & Seabream \\
\hline NeutralGlycoproteins & $1-3$ & 1 & 1 & $2-3$ & 2 & 2 \\
\hline Glycogen & 0 & 0 & 0 & 0 & 0 & 0 \\
\hline Sialoglycoproteins & 3 & 2 & 3 & 3 & 2 & 2 \\
\hline Sulphated-glycoproteins & 3 & 1 & 3 & $0-1$ & 3 & 3 \\
\hline Man/ Glc & 0 & 0 & 0 & 0 & 0 & 0 \\
\hline Fuc & 1 & 0 & 0 & 1 & 0 & 0 \\
\hline GlcNAc/Nana & $1-3$ & $1-3$ & 3 & 1 & $1-3$ & $1-3$ \\
\hline GalNAc & 0 & 0 & 0 & 0 & 0 & 0 \\
\hline Lipids & 0 & 0 & 0 & 0 & 0 & 0 \\
\hline Proteins & 1 & 0 & 2 & 1 & 2 & 2 \\
\hline$-S-S$ - groups & 2 & 1 & 0 & 2 & 1 & 1 \\
\hline
\end{tabular}

Intensity of reactions: 0: negative; 1: weak; 2: moderate and 3 strong histochemical reactivity.

salivary glands are normally lacking in fish, so that the oesophageal mucous cells might execute, among other things, the functions of mammalian saliva, i.e. protecting the mucosa of the entire alimentary canal (Scocco et al., 1998). In sturgeon, oesophageal mucous cells were Con A (Man and/or Glc residues) and WGA (GlcNAc and/or NANA) reactive. However, oesophageal mucous cells of sea bream and sole, as well mucous cells of skin, gills and intestine of all studied species were ConA unreactive The presence 

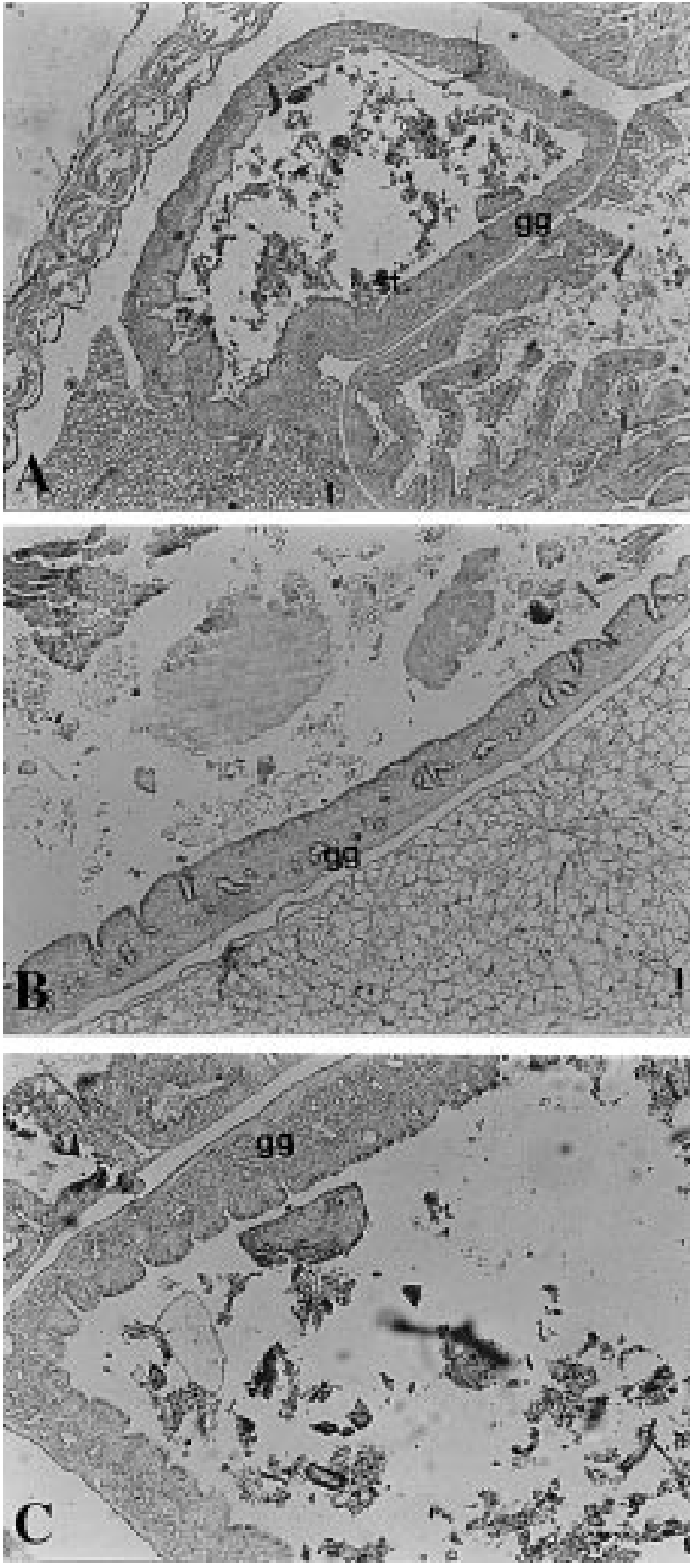

Fig. 2 - Histological sections of Siberian sturgeon, Acipenser baeri larvae. A) Gastric glands and intestinal mucosa containing Fuc residues. Larvae at 15 days post hatching. UEA-lectin x100. B) Presence of Man and/or Glc residues in glycoconjugates of the gastric glands. Larvae at 15 days post hatching. Con Alectin. x 100. C) Glycoconjugates containing GalNac residues in gastric glands of larvae at 15 days post hatching. DBA-lectin. x100. gg: gastric glands; l: liver; i: intestine: st: stomach. of WGA, Con A, UEA-I and DBA reactive granules in the epithelium and goblet cells of the Siberian sturgeon esophagus supports the concept that carbohydrate absortion occurs in this area, as was demostrated for other digestive sections (intestine and stomach) of adult fishes (Reifel and Travil, 1978; Scherbina et al., 1978; Madrid et al., 1989; Grau et al., 1992; Sarasquete et al., 1996). The absence of neutral mucosubstances and the presence of acidic glycoproteins at the oesophageal level may indicate a secretory rather than an absorptive function in fish (Kapoor et al., 1975; Grau et al., 1992),

\section{Stomach}

Developed gastric glands were detected very early, at 8-9 days posthatching, in Siberian sturgeon larvae development (Gisbert et al., 1998, 1999) and between 35 and 45 days posthatching in sea bream (Domeneghini et al., 1998) and Senegal sole (Vieira, 2000). These results have been related to metamorphosis in these species (Buddington and Christofferson, 1985; Sarasquete et al., 1995; Gisbert et al., 1998; Vieira, 2000). Sialosulphomucins were not observed in gastric glands of $S$. senegalensis, S. aurata and A. baeri, which contain neutral glycoproteins with GalNAc, Fuc, GlcNAc and Man and/or Glc sugar residues. However, glandular cells of S. aurata and A. transmontanus stomach were unreactive to the histochemical tests for glycoconjugates (Domeneghini et al., 1998, 1999). According to Domeneghini et al. (1998), GalNAc and GlcNAc residues could be identified in the sea bream gastric glands for a limited larval period only, but were no longer detectable in 100-day-old fish, probably because they were then in a sub-terminal position in the oligosaccharide branch. Only when the juvenile stage was reached did the adherent mucus gel appear to be composed of glycoconjugates containing $\mathrm{N}$-acetyl-galactosamine, $\alpha$-D-mannose, $\beta$ $\mathrm{D}$-galactose, L-fucose and $\mathrm{N}$-acetyl-glucosamine, in a pattern similar to that seen in sea bream adult fish (Domeneghini et al., 1998). These sugars probably occupy a terminal position in the glycoconjugates only when they are secreted to form the adherent mucus gel of the gastric mucosa.

The gastric mucosa of $S$. aurata, A. transmontanus (Domeneghini et al., 1998, 1999), A. baeri and $S$. senegalensis secretes a large quantity of neutral glycoconjugates, together with small amounts of sialoglycoconjugates. Secretion of neutral glycoconju- 

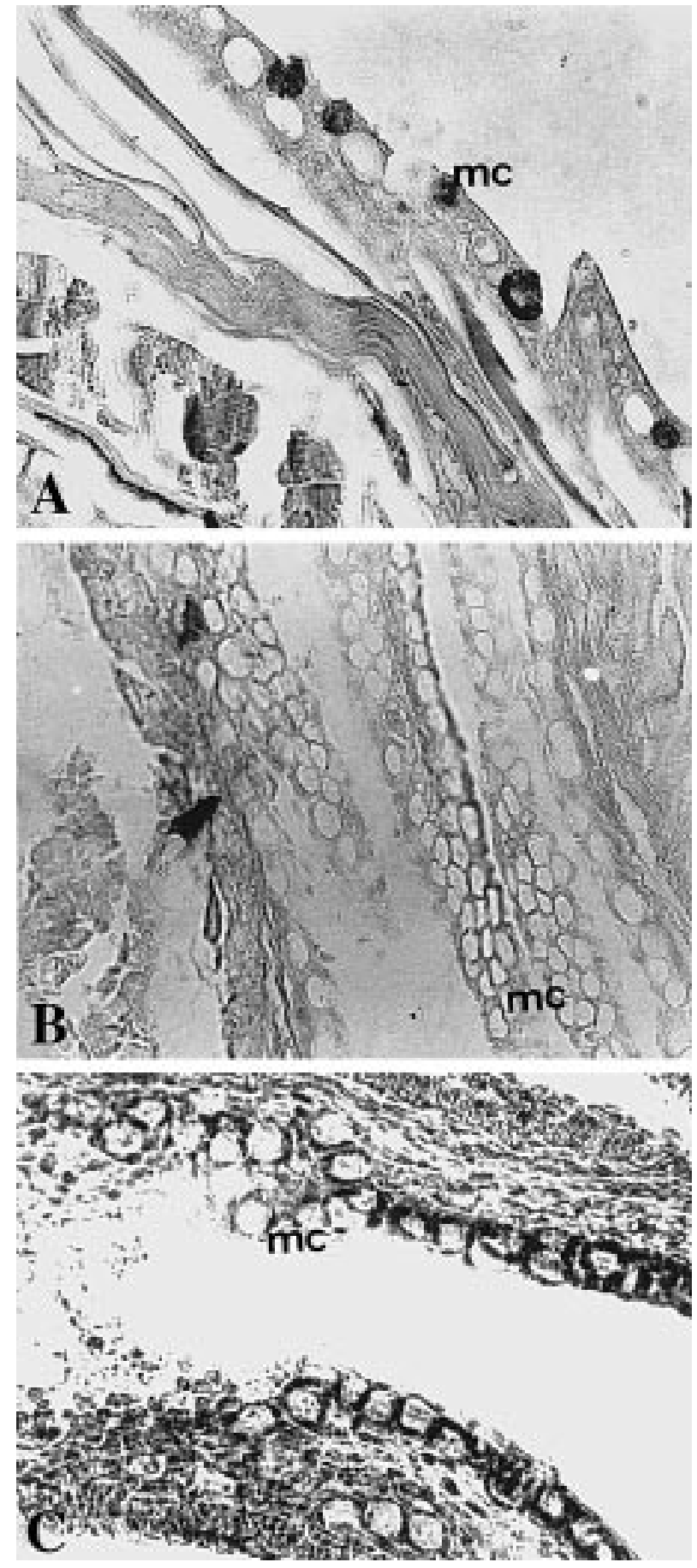

Fig. 3 - Histological sections of Senegales sole, Solea senegalensis and Sparus aurata larvae. A) Presence of glycoconjugates containing GlcNAc and/or sialic acid in epidermal mucous cells of Solea senegalensis larvae (15 days post hatching). WGAlectin. x400. B and C) Absence of Man and/or Glc residues in glycoconjugates present in oesophageal mucous cells of Solea senegalensis (A) and Sparus aurata (B) (larvae at 15 days post hatching). ConA-lectin. x400. mc: mucous cells. gates containing sugar residues has been observed in gastric glands of different fish species (Gutiérrez et al., 1986; Ferraris et al., 1987; Domeneghini et al., 1998; Gisbert et al., 1998, 1999), and may serve to protect the epithelium of stomach from autodigestion processes caused by $\mathrm{HCl}$ and enzymes produced in gastric glands (Ferraris et al., 1987). In fish, these glands are composed of one cell type, named "oxyntopeptic cell" (Reifel and Travill, 1978; Elbal and Agulleiro, 1986). These authors pointed out that the positive-PAS reaction seen on the surface of gastric epithelial cells resembles that seen in the striated border of intestinal enterocytes. This may indicate nutrient absorption occurring in the stomach. In fact, the presence of neutral mucins in the stomach has been related to the absorption of easily digestable substances such as disaccharides and short-chain fatty acids (Grau et al., 1992). Sulphated glycoproteins were negative in gastric glands of all studied species, but they were present in the stomach of a variety of other fish species (Reifel and Travill, 1978; Grau et al., 1992). Spicer and Schulte (1992) speculated that because of their known antipeptic activity, sulphomucins may be able to form a complex with pepsin, thereby stabilizing or buffering the enzyme.

The presence of proteins rich in tyrosine, arginine and tryptophan in developed gastric glands of all studied species suggests the presence of enzymatic precursors such as pepsinogen or digestive enzymes, as has been observed for different fish species (Medeiros et al., 1970 a,b; Gutiérrez et al., 1986; Grau et al., 1992; Gisbert et al., 1999; Douglas et al., 1999; Vieira, 2000).

\section{Intestine}

The presence of neutral glycoconjugates in the epithelium that lines the developing gut of different fish larvae suggests a secretory function of the intestinal epithelium (Domeneghini et al., 1998). The presence of neutral mucins and alkaline phosphatase activity in the brush border of intestinal epithelium has been positively correlated with absorption and transport of macromolecules through membranes (Stroband et al., 1979). Considering that the distal part of the gut of most fish species is capable of ingesting and digesting proteins via a pinocytotic pathway (Segner et al., 1994), and that this part shows maximal nutrient uptake capacity in the sturgeon (Buddington and Doroshow, $1986 \mathrm{a}, \mathrm{b}$ ), Domeneghini et al. (1999) assumed that the muco- 
Fig. 4 - Histological sections of Senegal sole, Solea senegalensis larvae/postlarvae. A) Glycoconjugates containing GlcNAc and/or sialic acid residues in gastric gland of Solea senegalensis postlarvae (45 days post hatching). WGAlectin. $x 400$. B) Glycoconjugates containing GlcNAc and/or sialic acid in intestinal mucous cells and gastric glands. Solea senegalensis postlarvae (45 days post hatching). WGA-lectin. x400. C) Glycoproteins containing cystine (-S-Sgroups) in intestinal mucosa of Solea senegalensis postlarvae ( 45 days potshatching). Ferric ferricyanide-Fe III and thioglycollate reduction. x 250. D) Neutral glycoproteins in gills of Solea senegalensis postlarvae (45 days post hatching). PAS-reaction. x250. gg: gastric glands; mc: mucous cells.
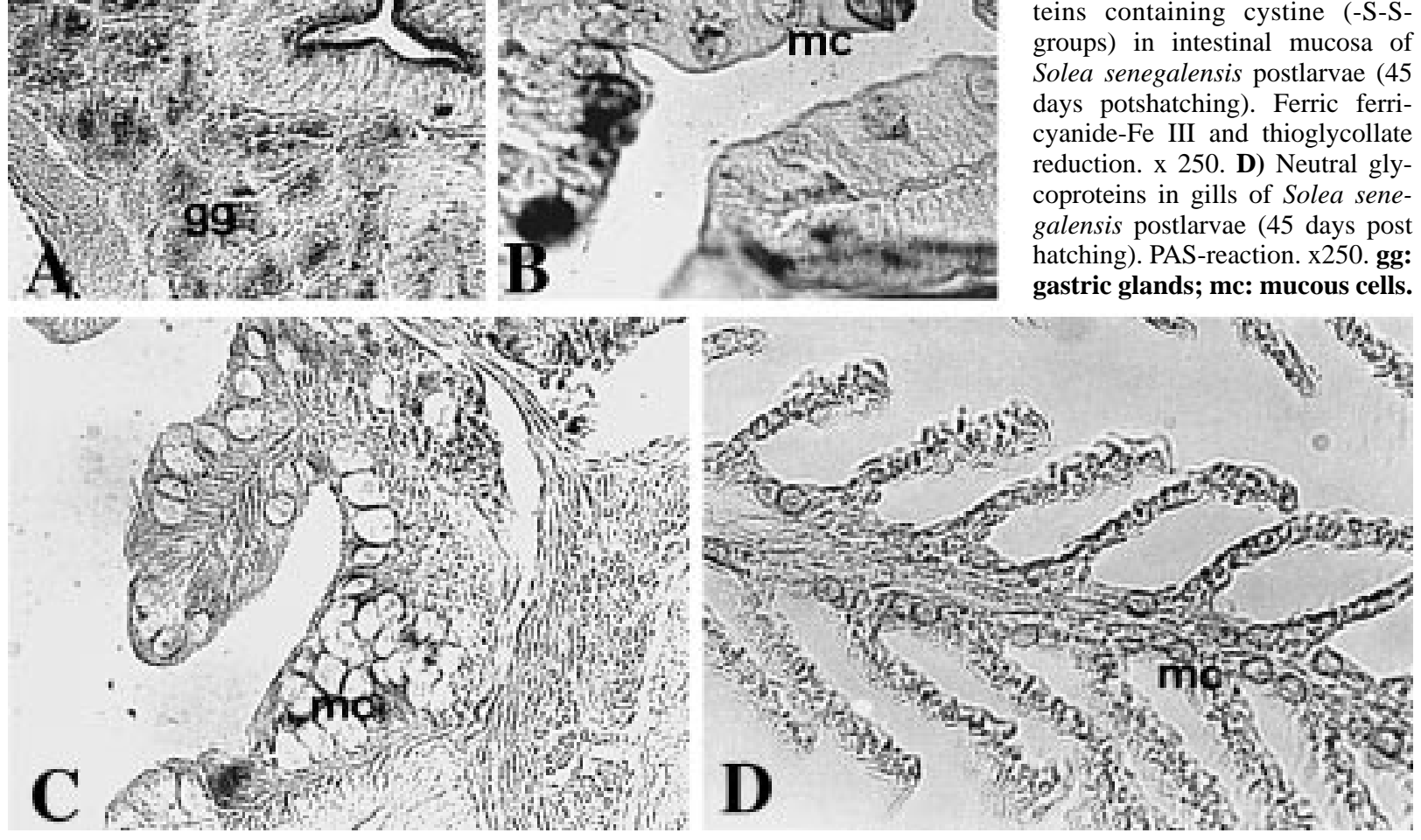

subtances, especially the sulphated ones, may regulate the transfer of protein or protein fragments.

The intestinal mucosa of sturgeon, A. transmontanus was organized in folds, containing numerous mucous cells which synthesized neutral or acidic glycoconjugates, the latter either of the sialylated or sulphated type. The sulphoglycoconjugates were more abundant in the mucous cells of the distal intestinal tract (Domeneghini et al., 1999). Similar results were observed in A. baeri. Most intestinal mucous cells of sea bream, sole and sturgeon larvae presented a combination of neutral and acidic gly- coproteins, while a few of them contained mainly acidic or neutral glycoproteins. Variability in staining within a given cell could be attributed to a temporal sequence in the biosynthesis of mucins (Harrison et al., 1987). The coexistence of neutral and acid glycoconjugates may be an indication of mucous cell differentiation with maturity (Elbal and Agulleiro, 1986; Murray et al., 1996). Intestinal mucous cells of all studied species were negative with the lipid techniques used, such as was observed in other fish species (Grau et al., 1992; Sarasquete et al., 1995; Ribeiro et al., 1999; Arel- 
lano et al., 1999). Some mucous cells of sole, sea bream and sturgeon were only positive to the PAS reaction, while other cells were weakly positive to bromophenol blue (proteins). With alcian blue $\mathrm{pH}$ 2.5-PAS double-staining, numerous cells were stained in red and/or blue and a few cells staining purple. Biosynthesis of mucin glycoconjugates includes at least two post-transcriptional modifications of the secretory protein: firstly glycosylation of the proteins, followed by modification of the sugar moiety (Phelps, 1978). According to Els and Hennerberg (1990), cells not staining with PAS contain only proteins. PAS-positive mucous cells might represent an early cell developmental stage, when the cells are producing mainly glycoproteins. Mucins stain with alcian blue ( $\mathrm{pH} 2.5$ ) when the glycoproteins are carboxylated, and the presence of sulphated glycoproteins ( $\mathrm{AB} \mathrm{pH} 0.5$ and 1) coincides with the stage when sulphated groups are conjugated to the glycoprotein. Similar observations were made by Arellano et al. (1999) in relation to glycoconjugate content of intestinal mucous cells of Solea senegalensis adult specimens.

The goblet cells of the intestinal mucosa of Siberian sturgeon, Senegal sole and sea bream larvae were WGA and DBA reactive, suggesting the presence of GalNAc and GlcNAc sugar residues. However, according to Domeneghini et al. (1998), these lectins do not bind to the intestinal mucosa of fishes younger than 70 days of age.

\section{Gills and Skin}

While epidermal mucous cells of all studied species and those of gills in Siberian sturgeon appear very early during larval development (around 3-4 days posthatching), branchial mucous cells appear around 40 days posthatching in sea bream and sole.

Mucous secretory products of skin, gills and digestive tract (oesophagus and intestine) do not contain lipids or glycogen; the general protein reaction (bromophenol blue) was negative in some cells and positive in others. Most mucous cells contain disulphide groups (-S-S-), supporting the glycoprotein nature of their secretions, as was suggested by Arellano et al. (1999).

The mucin content of mucous cells (digestive tract and/or skin and/or gills) of different fish species, larvae and adults, did not show any affinity towards LTA, UEA-I, LCA and Con A lectins (Madrid et al. 1989; Pajak and Danguy, 1993; Burkhardt-Holm,
1997; Domeneghini et al., 1998; Sarasquete et al., 1998; Ribeiro et al., 1999; Gisbert et al., 1999), suggesting the absence not only of Man and/or Glc residues, but also of Fuc in the carbohydrates involved. However, Con A (Man/Glc residues) reactivity occurred in epidermal mucous cells of Halobatrachus didactylus and Anguilla anguilla adult specimens (Illana et al., 1993), as well as in oesophageal mucous cells of Siberian sturgeon larvae (Gisbert et al., 1999). In rainbow trout, Oncorhynchus mykiss, UEA-I (L-Fuc residues) binds with differing intensities to mucous cells at the tip of the primary and secondary lamellae of gills (Burkhardt-Holm 1997). According to this author, D (+) galactose and Nacetyl-D-galactosamine sugar residues were detected in glycoconjugates of epidermal and branchial mucous cells of rainbow trout, but epidermal mucous cells were ConA and UEA unreactive.

Future studies are planned to examine the influence of environmental contaminants (detergents, heavy metals, organic lipophilic pollutants, etc) on the lectin-binding pattern, because it is known or supposed that numerous contaminants can produce changes in the $\mathrm{pH}$ of the water, and these variations could influence the lectin-binding pattern, as well as the mucous secretion-rate of epidermal and branchial fish mucous cells; thus, the histochemical methods could provide a good tool or indicator for environmental field studies.

\section{ACKNOWLEDGEMENTS}

The authors are grateful to D. Alfono Vidaurreta (Cupimar, S.A. San Fernando, Cádiz, Spain) for supplying the fish and to Dña Isabel Viaña for valuable technical assistance. This work was supported by Interreg II project (19/REGII/6/96); JNICT and CSIC (Portugal/Spain) and CYTMAR (MAR97-0924-CO2-01) projects. Special Thanks to Generalitat de Cataluya (Spain) for a F.I grant to D. Enric Gisbert (FI-PG95-1.144), as well as to Dr. Patrick Williot and Dr. Francesc CastellóOrvay for supervising part of this research.

\section{REFERENCES}

Allen, A.: Structure and function of gastrointestinal mucus. In Physiology of the gastrointestinal tract. Johnson L.R. (ed). Raven Press. New York. pp. 617-639, 1981. 
Arellano, J., Dinis, M.T., and Sarasquete, C.: Histomorphological and histochemical characteristics of the intestine of the Senegal sole, Solea senegalensis. Eur. J. Histochem. 43, 121133, 1999.

Arillo, A., Margiocco, C., and Melodia, F.: The gill sialic acid content as an index of environmental stress in rainbow trout, Salmo gairdneri, Richardson, J. Fish Biol. 15, 405-410, 1979.

Bancroft, J.D., and Stevens, A.: Theory and practice of histological techniques. In Bancroft J.D., and Stevens A. (Eds.). Churchill Livingstone, Edinburgh, London, Melbourne and New York. $3^{\text {a }}$ ed. pp. 726, 1990.

Boulhic, M., and Gabaudan, J.: Histological study of the organogenesis of the digestive system and swin bladder of the Dover sole, Solea solea (Linnaeus, 1758). Aquaculture 102, 373-396, 1992.

Buddington, R.K., and Christofferson, J.P.: Digestive and feeding characteristics of the chondrosteans. Environment Biology of Fishes 14, 31-41, 1985.

Buddington, R.K., and Doroshov, S.I.: Development of digestive secretions in white sturgeon juveniles (Acipenser transmontanus). Comp. Biochem. Physiol. 83A, 233-238, 1986a.

Buddington, R.K., and Doroshov, S.I.: Structural and functional relations of the white sturgeon alimentary canal (Acipenser transmontanus). J. Morphol. 190, 201-213, 1986b.

Burkhardt-Holm, P.: Lectin histochemistry of rainbow trout (Oncorhynchus mykiss) gill and skin. Histochem. J. 29, 893899, 1997.

Cousin, J.C.B., and Baudin-Laurencin, F. Morphogénêse de l'appareil digestif de la vessie gazeuse du turbot, Scophthalmus maximus L. Aquaculture 47, 305-319, 1985.

Domeneghini, C., Pannelle Straini, R., and Veggetti, A.: Gut glycoconjugates in Sparus aurata L. (Pisces.,Teleostei). A comparative histochemical study in larval and adult ages. Histol. Histopathol. 13, 359-372, 1998

Domeneghini, C., Arrighi, S. Radaelli, G., Bosi, G., and Mascarello, F.: Morphological and histochemical peculiarities of the gut in the white sturgeon, Acipenser transmontanus. Eur. J. Histochem. 43, 135-145, 1999.

Douglas, S.E., Gawlicka, A., Mandla, S., and Gallant, J.W.: Ontogeny of the stomach in winder flounder: characterization and expression of the pepsinogen and proton pump genes and determination of pepsin activity. J. Fish Biol. 55, 897-915, 1999.

Elbal, M.T., and Agulleiro, B.: A histochemical and ultrastructural study of the gut of Sparus auratus (Teleostei). J. Submicrosc. Cytol. 18, 335-347, 1986.

Els, W.J., and Hennerberg, R.: Histological features and histochemistry of the mucous glands in ventral skin of the frog, Rana fuscigula. Histol Histopath. 3, 343-348, 1990.

Ferguson, H.W., Morrison, D., Ostland, V.E., Lumsden, J., and Byrne, P.: Responses of mucus-producing cells in gill disease of rainbow trout, O. mykiss. J. Comp. Pathol. 106, 255-265, 1992.

Ferraris, R.P., Tan, J.D., and De La Cruz, M.C.: Development of the digestive tract of milkfish, Channos chanos. Histology and Histochemistry. Aquaculture 61, 241-257, 1987.

Fletcher, T.C.: Defence mechanisms in fish. In: Biochemical and biophysical perspectives in marine biology. Vol. IV. Malins D.C. and Sargent J.R. (eds.). Academic Press. London, pp. 189-222, 1978.

Gisbert, E., Rodriguez, A., Williot, P., and Castello-Orvay, F.: A histological study of the development of the digestive tract of Siberian sturgeon (Acipenser baeri) during early ontogeny, Aquaculture 167, 195-209, 1988

Gisbert, E., Sarasquete, M.C., Williot, P., and Castello-Orvay, F. Histochemistry of the development of the digestive system of Siberian sturgeon during early ontogeny. J. Fish Biol. 55, 596-616, 1999.

Gona, O. Mucus glycoproteins of teleostean fish, a comparative histochemical study. Histochem. J. 11, 709-718, 1979.

Grau, A., Crespo, S., Sarasquete, M.C., and Gonzalez De Canales, M.L. The digestive tract of the amberjack, Seriola dumerili. A light and scanning electron microscope study. J. Fish Biol. 41, 287-303, 1992

Groman, D.B.: Reproductive system. In: Histology of the stripped bass. Groman, D.B. (Ed.). American Fisheries Society. Bethesda, Maryland. Monograph. 3, 1982.

Gutierrez, M.: Nuevos colorantes biológicos y citohistoquímica de la coloración. Tesis doctoral. Facultad de Ciencias. Universidad de Cádiz. pp. 239, 1990.

Gutierrez, M., Sarasquete, C., and Gonzalez De Canales, M.L.: Distribución histoquímica de carbohidratos y proteínas en estómago e intestino de Anguilla anguilla L., 1758 de las salinas de Cádiz. Inv. Pesq. 50, 553-564, 1986.

Harrison, J.D., Auger, D.W., Paterson, K.L., and Rowley, P.S.A.: Mucin histochemistry of submandibular and parotic salivary glands of man: light and electron microscopy. Histochem. J. 19, 555-564, 1987

Illana, M.: Estudio histoquímico de residuos glucosilados de glucoproteínas en la piel de vertebrados. Tesis doctoral. Fac. de Medicina. Univ. de Cádiz. (España) pp. 157, 1993.

Kapoor, B.G., Smith, H., and Verighina, I.A.: The alimentary canal and digestion in teleosts. In Advances in Marine Biology, Vol. 13 (Russel, F.S., and Young, M., eds.) pp. 109-239. London: Academic Press, 1975.

Lemoine, A.M., and Olivereau, M. Presence d'acide N acétylneuraminique dans la peau d'Anguilla anguilla L. Intérêt de son dosage dans l'étude de l'osmoregulation. Z Vergl. Physiol. 73, 22-33, 1971.

Madrid, J.F., Ballesta, J., Castells, M.T; Marin, J.A., and Pastor L.M.: Characterization of glycoconjugates in the intestina mucosa of vertebrates by lectin histochemistry. Acta His tochem. Cytochem. 22, 1-14, 1989.

Medeiros, L.O., Ferri, S., Godinho, H., and Medeiros, L.F. Proteins and polysaccharides of the club-shaped cells in the lining epithelium of fish (Pimelodus maculatus) digestive tract: histochemical study. Ann. Histochem. 15, 181-186, 1970a. 
Medeiros, L.O., Ferri, S., Longhi L., and Worsmann, T.U. Histochemical study of protein in epithelial tissue of the digestive tract of Pimelodus maculatus Lacépède, 1803. Acta Histochem. 37, 113-117, 1970b

Morrison, C.M.: Histology of the Atlantic cod, Gadus morhua. Part Four. Eleutheroembryo and larva. Can. Spec. Publ. Fish. Aquat. Sci. 119, 496, 1993.

Murray, H.M., Wright, G.M., and Goff, G.P.: A study of the posterior esophagus in the winter flounder, Pleuronecte americanus, and the yellowtail flounder, Pleuronectes ferrug inea: a morphological evidence of pregastric digestion? Can J. Zool. 71, 1191-1198, 1994.

Murray, H.M., Wright, G.M., and Goff, G.P.: A comparative histological and histochemical study of the post-gastric alimentary canal from three species of pleuronectid, the Atlantic halibut, the yellowtail flounder and the winter flounder. J. Fish Biol. 48, 187-206, 1996.

Ortiz, J.B., Gonzalez De Canales, M.L., and Sarasquete, C. Cuantificación y alteraciones histopatológicas producidas por cocentraciones subletales de cobre en Fundulus heteroclitus. Cienc. Mar. 25, 119-143, 1999.

Pajak, B., and Danguy, A.: Characterization of sugar moietie and oligosacchraride sequences in the distal intestinal epithelium of the rainbow trout by means of lectin histochemistry. J. Fish Biol. 43, 709-722, 1993.

Pearse, A.G.E.: Histochemistry. Theoretical and applied. vol 2 Analytical Technology, $4^{\text {th }}$ ed. Churchill Livingstone. New York. NY. pp. 1055, 1985.

Phelps, C.F.: Biosynthesis of mucus glycoprotein. Br. Med. Bull. 34, 43-48, 1978

Reifel, C.W., and Travill, A.A.: Structure and carbohydrate histochemistry of the esophagus in ten teleostean species. J. Morphol. 152, 303-314, 1977.

Reifel, C.W., and Travill, A.A.: Structure and carbohydrate histochemistry of the stomach in eight species of teleosts. J. Morphol. 158, 155-168, 1978

Reifel, C.W., and Travill, A.A.: Structure and carbohydrate histochemistry of the intestine of ten teleostean species. J. Morphol. 162, 343-360, 1979.

Rhodes, J.M. Black, R.R., Gallimore, R., and Savage, A.: Histochemical demonstration of desialitation and desulphation of normal and inflammatory bowel disease rectal mucus by faecal extracts. Gut 26, 1312-1318, 1985.

Ribeiro, L., Sarasquete, C., and Dinis, M.T.: Histological and histochemical characteristics during development of the Senegal sole, Solea senegalensis. Aquaculture 171, 291-306, 1999

Roberts, R.J. Fish pathology. Roberts R.J. (ed). University Press. Aberdeen, pp. 318, 1978.

Sarasquete, M.C., Polo, A., and Gonzalez De Canales, M.L.: A histochemical and immunohistochemical study of digestive enzymes and hormones during the larval development of the sea bream, Sparus aurata L. Histochem. J. 25. 430-437, 1993.
Sarasquete, M.C. Polo, A., and Yufera, M.: Histology and histochemistry of the development of the digestive system of larval gilthead seabream, Sparus aurata L. Aquaculture 130 78-92, 1995

Sarasquete, C., Gonzalez De Canales, M.L., Arellano, J.M., Muňoz-Cueto, J.A. Ribeiro, L., and Dinis, M.T.: Histochemical aspects of the yolk-sac and digestive tract of larvae of the Senegal sole, Solea senegalensis (Kaup, 1858). Histol. Histopathol. 11, 881-888, 1996.

Sarasquete, C. Gonzalez De Canales, M.L., Arellano, J.M Muňoz-Cueto, J.A., Ribeiro, L., and Dinis, T.: Histochemical study of skin and gills of Senegal sole, Solea senegalensis larvae and adults. Histol. Histophathol. 13, 727-735, 1998.

Scocco, P., Ceccarelli, P., and Menghi, G.: Glycohistochemistry of the Tilapia spp. stomach. J. Fish Biol. 49, 584-593, 1996

Scocco, P., Accili, D., Menghi, G., and Ceccarelli, P.: Unusual glycoconjugates in the oesophagus of a tilapine polyhybrid. J. Fish Biol. 53, 39-48, 1998.

Scherbina, M.A., Scherbina, T.V., and Kazlauskene, O Amylase activity and rate of carbohydrate resorption with the introduction of various amounts of fat into diet of the carp, Cyprinus carpio. J. Ichthyol. 17, 327-331, 1978.

Segner, H., Storch, V., Reinecke, M., Kloas, W., and Hanke, W.: The development of functional digestive and metabolic organs in turbot, Scophthalmus maximus. Mar. Biol. 119. 471-486, 1994

Smith, L.S.: Digestive functions in teleost fishes. In: Halver J.E. (ed.) Fish nutrition, San Diego, Academic Press, pp. 331$421,1989$.

Spicer, S.S., and Schulte, B.A.: Diversity of cell glycoconjugates shown histochemically: a perspective. J. Histochem. Cytochem. 40, 1-38, 1992.

Stroband, H.W.J., Meer, H.V.D., and Timmermans, L.P.M. Regional functional differentiation in the gut of the grass-carp, Ctenopharyngodon idella. Histochemistry, 64, 235-249, 1979.

Strous, G.J., and Dekker, J.: Mucin-type glycoproteins. Crit. Rev. Biochem. Mol. Biol. 27, 57-92, 1992.

Tibbets, I.R.: The distribution and function of mucous cells and their secretions in the alimentary tract of Arrhamphus sclerolepis krefftii. J. Fish Biol. 50, 809-820, 1997.

Wendelaar Bonga, S.E., and Lock, R.A.C.: Toxicants and osmoregulation in fish. Neth. J. Zool. 42, 478-493, 1992.

Zimmer, G., Reuter, G., and Schauer, R.: Use of influenza cvirus for detection of 90 -acetylated sialic acids on immobilized glyconjugates by esterase activity. Eur. J. Biochem. 204 209-215, 1992

Vieira, L.I.: Histologia e histoquimica do tubo digestivo e órganos anexos de pós-larvas e juvenis de Solea senegalensis (Kaup, 1858) alimentados con diferentes dietas. Universidade do Algarve. Faro. Portugal, pp. 97, 2000 